International Business and Global Economy 2017, no. 36, pp. 288-308

Biznes międzynarodowy w gospodarce globalnej 2017, nr 36, s. 288-308

Edited by the Institute of International Business, University of Gdańsk

ISSN 2300-6102

e-ISSN 2353-9496

DOI 10.4467/23539496IB.17.020.7468

Kamran Davari Nikou

Dokuz Eylul University, Graduate School of Social Sciences

\title{
Terminology, traits, types, and trajectory of new product development
}

The purpose of this study is to present the terminology, traits, types, transformation, and trajectory of new product development (NPD) from an interdisciplinary perspective, compare the traditional and modern models, and analyse the side effects of NPD. A descriptive and, in some cases, chronological method is used for data analysis. Data has been gathered from more than a hundred credible literature and online sources. The subject matter is discussed in the context of marketing, engineering, strategy, management, and innovation in order to compile a typology and compare traditional and modern models, counter models, and side effects of NPD. Academic NPD literature has been around for only fifty years and is still relatively young. The study uncovers the transformations of new products and services throughout history, thereby revealing the secrets of a really productive NPD - this however, might not be enough, since the future is too fuzzy, complicated, multi-dimensional, and full of discontinuities.

Keywords: new product development, new service development, typology, trajectory

JEL classification: A12, M1, M31, O14, O32

\section{Tworzenie nowych produktów -} terminologia, charakterystyka, typologia i ścieżka rozwojowa

Celem niniejszej pracy jest przedstawienie z perspektywy interdyscyplinarnej terminologii, charakterystyki, typologii, przeobrażeń oraz ścieżki rozwojowej procesu tworzenia nowych produktów (NPD), porównanie tradycyjnych i nowoczesnych koncepcji oraz analiza skutków ubocznych. Do analizy danych wykorzystano metodę opisową oraz, w niektórych wypadkach, chronologiczną. Dane do badań pozyskano z ponad stu wiarygodnych źródeł literaturowych i internetowych. Przedmiot badań omówiono w kontekście marketingu, techniki, strategii, zarządzania i innowacji celem nakreślenia typologii oraz porównania tradycyjnych i nowoczesnych koncepcji, kontrmodeli oraz skutków ubocznych NPD. Literatura fachowa poświęcona tworzeniu nowych produktów ukazuje się dopiero od pięćdziesięciu lat, jest więc stosunkowo młoda. Badanie ukazało przeobrażenia, które dokonały się na przestrzeni czasu w procesie tworzenia nowych produktów i usług, odkrywając tym samym tajemnice prawdziwie produktywnych procesów NPD - to może jednak nie wystarczyć, gdyż przyszłość jest mglista, złożona, wielowymiarowa i pełna niekonsekwencji.

Słowa kluczowe: tworzenie nowych produktów, tworzenie nowych usług, typologia, ścieżka rozwojowa

Klasyfikacja JEL: A12, M1, M31, O14, O32 


\section{Introduction}

In our complex, interconnected, and challenging world, characterised by serious and intense global competition in the development of new products and services, countries attempt to design, produce, develop, and sell new products to inject a fresh spirit to their economy. This is why in the current challenging environment efficient and fast commercialisation becomes a top priority and a critical concern for businesses [Harmancioglu et al., 2007, p. 421; Filippini, Salmaso, Tessarolo, 2004, p. 199; Bonner, Ruekert, Walker, 2002, p. 234], whose long-term viability and competitiveness depends on it [Paashuis, 1998, p. 1; Calantone Schmidt, Song, 1996, p. 342; Song, Neeley, Zhao, 1996, p. 546].

The present paper aims to paint the big picture of new product development (NPD) by putting together the pieces of a puzzle - including terminology, morphology, typology, and trajectory of NPD - and presenting them from a crossdisciplinary perspective. Its additional aim is to discuss the traditional and modern models, counter models, and side effects of NPD.

Plentiful evidence indicates that efficacious new product development has positive influence on the survival and affluence of modern corporations [Cooper, 2013, p. 3] by granting them first-mover advantage [Rhee, 2015, p. 9], long-run competitive advantage [Palmer, 2009, p. 277], sustainable performance [Ernst, 2002, p. 1], core competencies and differentiation from competitors [Prahalad, Hamel, 1990, p. 80], and threshold capabilities [McCarthy et al., 2006, p. 437], which help them shape customer expectations and meet their future needs. NPD, which occupies a central position in business, turns into a self-renewing pool of capabilities [Wheelwright, Clark, 2007]. Marketers should acknowledge the need to develop products in response to shortening life-cycle, which result in fast changing technology and competition pressures [Palmer, 2009, p. 276].

Globalisation, characterised by high customer expectations, short lead times, and thin profit margins, forces enterprises to take advantage of any opportunity to optimise their business tactics [Davari Nikou, 2011, p. 212]. Each day, as the expectations of consumers and the number of alternative products and services increase dramatically, customer loyalty decreases. Technologists, managers, and marketers collaborate to reach a set of common goals, including - simplicity, costeffectiveness, increased number of applications, adaption to changing conditions, optimisation, and risk-reduction. Therefore knowing and learning the terminology, traits, types, and trajectory of new product development is vital and fruitful for theorists and practitioners. 


\section{Methodology}

The purpose of this study is to present the terminology, traits, and trajectory of new product development from an interdisciplinary perspective. A descriptive and, in some cases, chronological method is used for data analysis. Data has been gathered from literature and online sources. On this basis, the trajectory and evolution of NPD is illustrated. Then, a comparison of traditional and modern NPD models is carried out. Finally, the side effects of NPD are analysed.

\section{Terminology}

Because of its multidisciplinary nature and despite its young age, the NPD literature is vast and diverse. Unlike today, when libraries and archives are overflowing with papers and books on the subject, before the 1960s novelty and innovation was one of the untouched and least considered business issues.

\subsection{New product development}

New product development is an interdisciplinary concept, which combines technology, management, engineering, marketing, production, economy, art, and actual solutions in order to obtain competitive advantage. In a classic sense, it means 'extending the lives and expanding the markets of existing products by adding new features, styles, packaging, and pricing' [Levitt, 1966, p. 67]. In other words, it is a system incorporating the dynamic and vigorous interactions between internal and external elements [Harmancioglu et al., 2007, p. 421].

'Building capabilities' - such as knowledge, method, and motivation - allow firms to meet the future needs of their customers, and NPD makes it possible for them to convert market opportunities or sets of guesstimates about product technology into a commercialised good or service available for sale [Krishnan, Ulrich, 2001] by introducing 'improvements or revisions to existing products, additions to existing lines, "new to the world" products, and repositioning' [Palmer, 2009, pp. 277-278]. All in all, NPD could be defined as a process of transforming ideas (derived from market needs, technology push, systematic novation, and even haphazard innovations and occasional opportunities) into saleable new products, services, plans, patents, or ideas.

\subsection{New service development}

Dictionaries define the term 'service' as 'providing a particular thing that people need', 'the particular skills that someone has and can offer to others', and 
'contribution to the welfare of others'. Services can be categorised as deeds, processes, and performances [Wilson et al., 2012, p. 5]. A more fresh perspective also speaks of 'benefits without ownership' [Lovelock, Wirtz, Chew, 2012, p. 12; Ng, 2014, p. 4].

New service development (NSD) is a fundamentally cross-functional activity that needs to adopt an integrated and multidisciplinary viewpoint. As an organisational process, it combines marketing and operational aspects in order to develop and implement services valued by customers [Tatikonda, Zeithaml, 2002, p. 201]. NSD allows industrialised firms to differentiate market offerings and attain competitive advantage [Witell et al., 2014, p. 35]. Technological novelty alone is not enough to optimise the differentiation of market offerings [Gremyr et al., 2014, p. 123; Kowalkowski et al., 2012, p. 765], which is why 'hybrid offerings' are being introduced as an alternative way of building distinctive capabilities by merging products and services [Ulaga, Reinartz, 2011, p. 5]. Consequently, manufacturers have to not only create novel technological adjustments to survive, contest, and grow but also to launch service development strategies to gain competitive advantage through 'service innovations' [Gremyr et al., 2014, p. 123; Santamaría, Nieto, Miles, 2012, p. 144; Moreau, Tether, 2010, p. 27]. Organisations seek out new means of differentiation placing a greater emphasis on services, which is often referred to as 'service infusion' [Kowalkowski, Witell, Gustafsson, 2013, p. 18].

Effective NSD involves continuous modifications, recalibration of opportunities, seizing of ad hoc innovation, and uninterrupted adjustments of intertwining goals [Kowalkowski et al., 2012, p. 765]. Intangibility, inseparability, variability, and perishability are what distinguish services from goods [Shekar, 2007, p. 3]. This is why, although NSD builds upon NPD [Gremyr et al., 2014, p. 129], the different nature of services affects the development criteria [Lovelock, Wirtz, 2014, pp. 298, 322].

\section{Traits}

\subsection{Marketing}

Marketing gains its importance in the prelaunch phases of NPD, as new product ideas emerge from market research and such external sources as 'identification of untapped needs' [Palmer, 2009, p. 281] and 'watching and listening to consumers' [Kotler, Armstrong, 2003, p. 325]. In the late 1970s, the notion of 'customer involvement' and 'customer-active paradigm' significantly increased the role of the customer in NPD [Krishna, Kautish, 2012, p. 119]. Marketing skills, product strategy, technology sources [Mendes, Ganga, 2013, p. 93], quality and cost of product, time, cost and capability for development [Iamratanakul, Patanakul, Milosevic, 2008, 
p. 188] are predictors of NPD success. Brand equity facilitates the acceptance of new products, and due to the costs and failure rate of NPD numerous firms prefer to establish brand extensions instead of risking launching new brands [Schiffman, Kanuk, 1997, p. 224]. At the same time, such new tendencies as anti-consumption, consumer rebellion, customer resistance, and brand rejection constitute threats to conventional marketing. Recognising and understanding market trends can help companies to create a design strategy and diffusion strategy and diversify product portfolio [Higham, 2009, p. 30]. Marketers should explore the requirements to develop new products in repercussion to shortening product life cycle which originate from speedy technology shift and pressures that are triggered by competition [Palmer, 2009, p. 276]. Diffusion and adoption should become the subject of consideration after the NPD process has been completed. Diffusion, as a macro process, is the spread out of any type of innovation (ideas, goods, services, practices, or experiences) from origin till consuming by public. Adoption, as a micro process, concerns the reception or rejection of new products by customers [Schiffman, Kanuk, 1997, p. 552]. Understanding of the customer and involving him through service supporting mutual action among supplier and customer in the development process would create extra value for both sides in the long-run [Pekkarinen, Salminen, 2013, p. 165]. Moreover, improved marketing-manufacturing integration in each phase of NPD gives companies greater competitive advantage [Swink, Song, 2007, p. 203].

\subsection{Engineering}

Nowadays, as a universal tendency, 'enhancing innovation abilities' is the number one driver of corporate progression and prosperity; only a decade ago, however, the focus of organisations was 'cost cutting' [Little, 2005, p. 6]. New products are usually developed by scientists and engineers who modify the existing products and technologies to make them healthier, easier to use, and more cost-effective [Durgee, O'Connor, Veryzer, 1998, p. 525]. Facilitating the conversion of customer needs and desires into technical requirements for NPD supports the integration of the technical and administrative roles engaged in development efforts [Jugend, Silva, 2012, p. 60]. The development of new products accelerates due to the wish to create a differential advantage (product differentiation), achieve technological breakthroughs, and respond to changing demographics [Murthy, Rausand, Osteras, 2008, p. 18].

\subsection{Innovativeness}

Levitt [1966, pp. 65-68] suggests a progressive way of developing new products in the name of innovative imitation, which tends to be random, accidental, 
reactive, and can result in design and development, reverse R\&D, and breakthrough newness.

Newness is defined as the degree of change [Tatikonda, Zeithaml, 2002, p. 214]. It is subjectively assigned to a product by the observer (producer, buyer, payer, user) and thus could be defined as 'the degree to which a given product is outside the observer's experience' [Blythe, 1999: 419]. The type of newness affects the selected marketing strategy [Micheal, Rochford, Wotruba, 2003, p. 270]. Six aspects of innovation are distinguished, concerning products, services, methods of production, markets, sources, and organisation [Johannessen, Olsen, Lumpkin, 2001, p. 21]. A product can be new to the world, the industry, the manufacturing firm, the market, or the customer - new in terms of technology, processes, features, uses, and designs [Murthy, Rausand, Osteras, 2008, p. 18].

Some concepts, contexts, and referents related to the idea of newness are summarised in Table 1.

Table 1. Novelty and newness in products and services

\begin{tabular}{|c|c|c|}
\hline Concept & Context & Referent \\
\hline \multirow{5}{*}{$\begin{array}{l}\text { newness } \\
\text { degree of change } \\
\text { unfamiliarity to the observer } \\
\text { contact between innovative } \\
\text { products and consumers }\end{array}$} & what? & $\begin{array}{l}\text { new products and services } \\
\text { new methods of production } \\
\text { new markets } \\
\text { new sources of supply } \\
\text { new organisation systems } \\
\text { revision or improvement of existing products } \\
\text { revision or improvement of existing services }\end{array}$ \\
\hline & why? & $\begin{array}{l}\text { differential advantage } \\
\text { product differentiation } \\
\text { continued growth of manufacturers } \\
\text { benefits from technological breakthroughs } \\
\text { relocation and cost reduction } \\
\text { response to changing demographics }\end{array}$ \\
\hline & how? & $\begin{array}{l}\text { new technology } \\
\text { new process } \\
\text { new features } \\
\text { new uses } \\
\text { new design }\end{array}$ \\
\hline & for whom? & $\begin{array}{l}\text { new to the world } \\
\text { new to the industry } \\
\text { new to the manufacturer } \\
\text { new to the market } \\
\text { new to the customer }\end{array}$ \\
\hline & range of change & $\begin{array}{l}\text { from incremental to radical } \\
\text { from micro to macro } \\
\text { from minor to major }\end{array}$ \\
\hline
\end{tabular}

Source: Own elaboration based on: [Murthy, Rausand, Osteras, 2008; Tatikonda, Zeithaml, 2002; Johannessen, Olsen, Lumpkin, 2001; Blythe, 1999; Booz Allen Hamilton Inc., 1982]. 


\subsection{Strategy}

Since new products are necessary to ensure success of companies, they must develop constructive NPD strategies and avoid wasting funds, time, effort, and energy as well as spreading confusion and disappointment among employees. The link between business strategy and technology strategy [Zapata, Cantú, 2008, p. 113] is a dominant factor that should be taken into consideration by policymakers, who are expected to outline a unified direction of the NPD process in the following aspects: 'technology/market mix, market width, degree of innovation/imitation, price/quality ranges and product/service relatedness' [Crawford, 1972, p. 50]. Success in the market calls for resources, strategies, and tactics [Brentani, Kleinschmidt, Salomo, 2010, p. 143]. Rigorous interpreting the fads, tendencies, trends and mega trends can support firms to design NPD strategy, product portfolio diversification and diffusion strategy [Higham, 2009, p. 30].

\subsection{Management}

Some of the NPD leading researchers advise combining an agile and a lean approach to overcome the rigidness of traditional product design [Jaruzelski, Holman, Duad, 2001] and carry out multi-partner R\&D projects [Mishra, Chandrasekaran, MacCormack, 2015, p. 12].

A highly-motivated team and effective information flow from the source to the final user are of great importance to the success of NPD [Griffin, 1992, p. 171]. It is crucial to remember that unilateral batch communications may lead to discouragement [Paashuis, 1998, p. 28; Clark, Fujimoto, 1991, p. 210], and that informal communications have a much better effect on group effort than formal ones [Kyriazis, Massey, 2008, p. 6]. Companies with formalised interactions have a tendency for managerial bias and unidirectional flows of ideas, while in those in which the NPD procedure is elastic, the flow of information is bidirectional and socially-oriented [Felekoglu, Maier, Moultrie, 2013, p. 395].

\subsection{Success and failure}

A number of critical success factors can be found discussed in the NPD literature [Scott, Govender, Merwe, 2016; Cooper, 2013; Kahn et al., 2012; Bhuiyan, 2011; Barczak, Griffin, Kahn, 2009; Ernst, 2002; Flint, 2002; Goldenberg, Lehmann, Mazursky, 2001]. Although there is no guarantee of success, taking a systematic approach and caring about former pitfalls helps to mitigate the risk and increases the probability of success [Cooper, 1983, p. 10]. Thus failure is the price to be waged for success [Poolton, Barclay, 1998, p. 198; Hopkins, Bailey, 1971]. 
Successful NPD can be conceived as a generic target of R\&D departments [Suomala, Jokioinen, 2003, p. 213]. Organisations attempt to shorten the NPD period [Griffin, 1993, p. 112], because under conditions of increasing global competition and prompt, unexpected, and profound changes, interruption or delay in accomplishing core competencies may prevent success [Harmancioglu et al., 2007, p. 421]. Success or failure of NPD performances also depends on 'product quality, product cost, development time, development cost, and development capability' [Iamratanakul, Patanakul, Milosevic, 2008, p. 188], as well as 'marketing skills, product strategy, technology sources, and execution quality of NPD activities' [Mendes, Ganga, 2013, p. 93]. NPD success happens by design, not by accident [Cooper, 2013, p. 28].

\section{Transformations and trajectory}

\subsection{Historical background}

Despite its young age, academic NPD literature has an old and deep historical background. The phrase 'new product development' conveys novelty and newness, but its roots date to prehistoric times. When the human being discovered fire and came out of the caves, the development of new products was initiated. NPD idea generation can clearly be considered the factor that sparked the process of change and pushed humanity through the ages of stone, bronze, and iron, and into the times of machines, electricity, atom, space, microelectronic, biotechnology, and virtual networks. Rather than chronological concern, Iinnovation always constituted a powerful survival tool, the engine of progress, and the reason behind increasing the quality of life [Atkinson, Wial, 2008, p. 2; Abernathy, Clark, 1985, p. 3]. Creative ideation has not only provided competitive advantage and livelihood for businesses [Scott, Govender, Merwe, 2016, p. 308] but also supported civilisations in many aspects [Muller, 2015, p. 1].

\subsection{Evolution}

When discussing NPD, Goldenberg and Mazursky [2002, p. 23] refer to Darwin's theory of evolution, stating that products are developed in response to 'environmental pressures' - in terms of market needs, wants, demand, and desires - in a process that resembles 'the survival of the fittest'. The evolution of NPD can be divided into six periods. 
Table 2. The evolution of new product development

\begin{tabular}{|c|l|}
\hline Decade & \multicolumn{1}{c|}{ Main trends } \\
\hline $1960 \mathrm{~s}$ & the birth of the concept of NPD \\
\hline $1970 \mathrm{~s}$ & emphasis on the process of NPD \\
\hline $1980 \mathrm{~s}$ & emphasis on the strategy of NPD \\
\hline $1990 \mathrm{~s}$ & tracking of NPD metrics \\
\hline $2000 \mathrm{~s}$ & $\begin{array}{l}\text { emphasis on knowledge management, methodical engineering, } \\
\text { value engineering }\end{array}$ \\
\hline $2010 \mathrm{~s}$ & emphasis on greening, sharing, futuristic outlook, holistic approach \\
\hline
\end{tabular}

Source: Own elaboration based on: [Morgan et al., 2015, p. 743; Jugend, Silva, 2012, p. 60; Krishna, Kautish, 2012, p. 119; Anderson, 2008, p. 558; Swink, Song, 2007, p. 203; Cooper, Edgett, 2001, p. 4; Shah, Kulkarni, Vargas-Hernandez, 2000, p. 378; Cooper, 1993, p. 4; Takeuchi, Nonaka, 1986, p. 137; Alford, Mason, 1975: 27].

\section{Typology}

NPD is a continuous [Owens, Davies, 2000, p. 10], extended, and lengthy process triggered by idea generation and closed by a fruitful and effective market take-off [Haverila, 1995, p. 1]. It is one of the most risky but, at the same time, essential activities undertaken by contemporary businesses [Cooper, 1993, p. 4; Ozer, Chen, 2006, p. 282]. Some of the most common NPD models are discussed below.

\subsection{Classic model}

Booz Allen Hamilton Inc. introduced an already classic division of the NPD process into seven stages, illustrated in Figure 1 below.

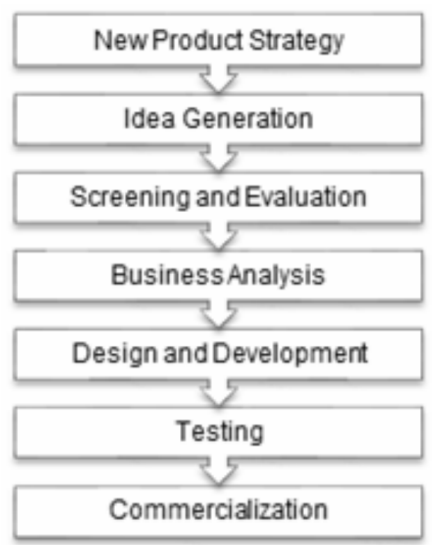

Figure 1. Classic stages of new product development Source: [Bhuiyan, 2011, p. 749; Booz Allen Hamilton Inc., 1982]. 


\subsection{Sequential model}

One of the traditional and fundamental models of NPD is the sequential model. Its main characteristic is that within this framework passing to the next stage is possible only if the former stage has been completed. Its overall deficiency is the lack of holistic view, which stems from the fact that the flow of ideas, information, and decisions between the departments is not fast and fluent enough, thereby hindering inter-departmental cooperation [Owens, Davies, 2000, p. 7].
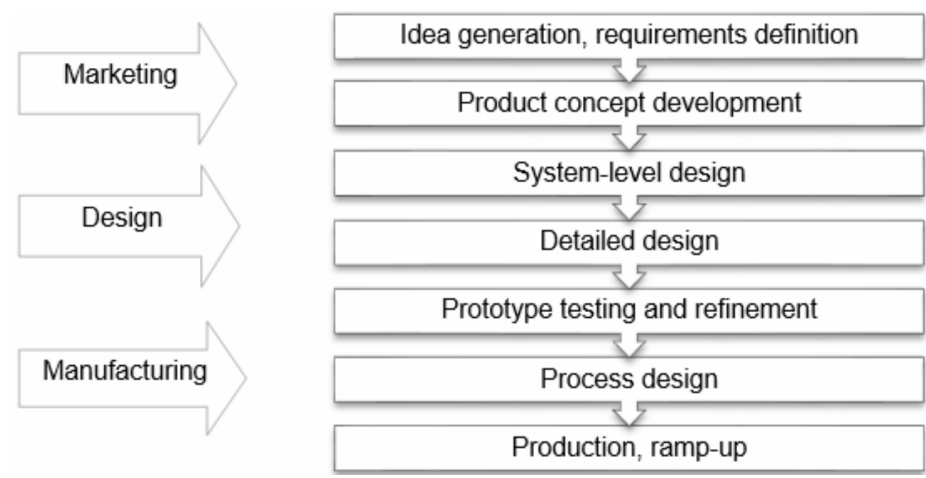

Figure 2. Sequential model of new product development

Source: [Owens, Davies, 2000, p. 7; Ulrich, Eppinger, 1995; Russell, Taylor, 1995].

\subsection{Eight-stage model}

Kotler and Armstrong [2010, p. 261] present NPD as a methodical process consisting of eight main steps, aimed at creating new customer-focused products and services and value added for the consumers.

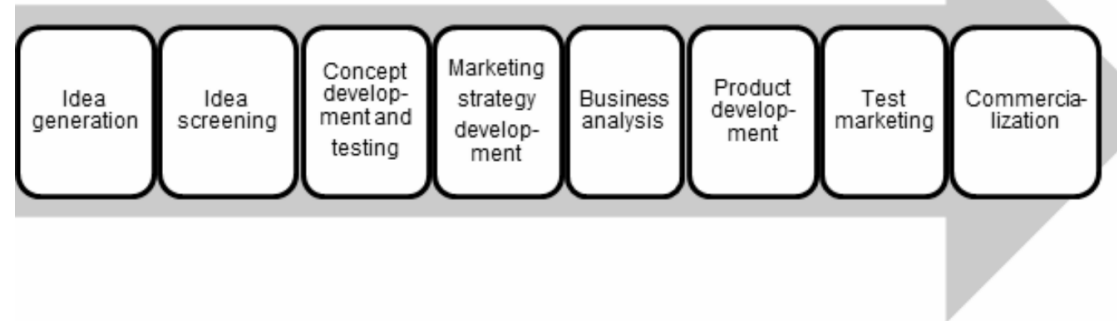

Figure 3. Main stages in new product development

Source: [Kotler, Armstrong, 2010, p. 261]. 


\subsection{Creativity in the innovation process}

According to Couger [qtd. in Ahonen, 2005, p. 549], innovation means transforming raw ideas into merchandise, services, and technologies. Creativity is presented as an inseparable and integral component of the innovation process, which encompasses four sequential phases: discovery, invention, innovation, and patent registration.

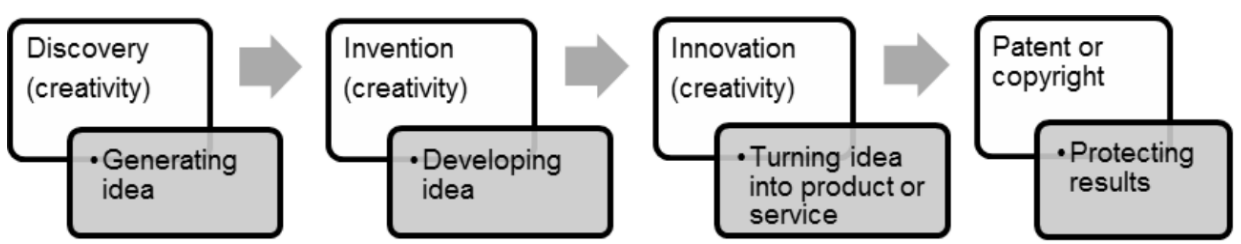

Figure 4. Creativity in the innovation process Source: [Couger, 1995].

\subsection{Fuzzy front end}

The phrase 'front end' denotes the activities performed at the very beginning of the NPD process, also termed 'pre-development' [Cooper, 2015, p. 4; Cooper, Kleinschmidt, 1994], 'pre-project' [Verganti, 1997, p. 377], 'pre-phase 0' [Khurana, Rosenthal, 1998], and 'fuzzy front end' [Herstatt et al., 2004, p. 3; Deppe et al., 2002, p. 3]. Directors were in trouble because mechanisms of fuzzy front end were fairly unidentified. These activities include, i.a., identification of opportunity, concept definition, task description, business analysis, selection idea, prototype building, testing, and project planning [Nordlund, Poskela, 2005, p. 5].

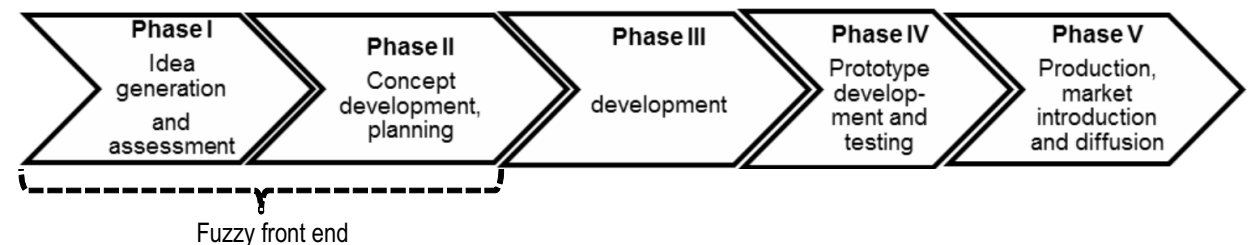

Figure 5. New product development with fuzzy front end

Source: [Herstatt, Verworn, Nagahira, 2004, p. 4].

\subsection{Four stages of the innovation process}

Majaro [qtd. in Ahonen, 2005, p. 548] proposes an innovation process comprised of four stages: developing ideas, checking their harmonisation with the firm's 
intentions, a study of technical and commercial feasibility, and finally implementation.

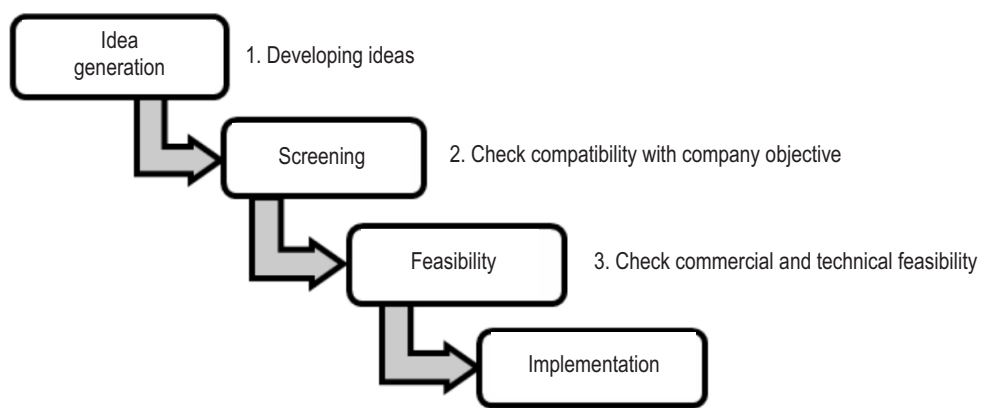

Figure 6: Four stages of the innovation process

Source: [Majaro, 1988].

\subsection{Five-stage idea to launch the Stage-Gate System}

After proposing a seven-stage (idea, preliminary assessment, concept, development, testing, trial, launch) model of the NPD process, Cooper suggested another, five-stage model composed of prescribed, synchronised, and confirmed activities to be undertaken by a cross-functional team, including solid front-end exercises, rigorous fact-based product definition, spiral development model, and voice of the customer [Cooper, 1983, p. 7; 2013, p. 29].

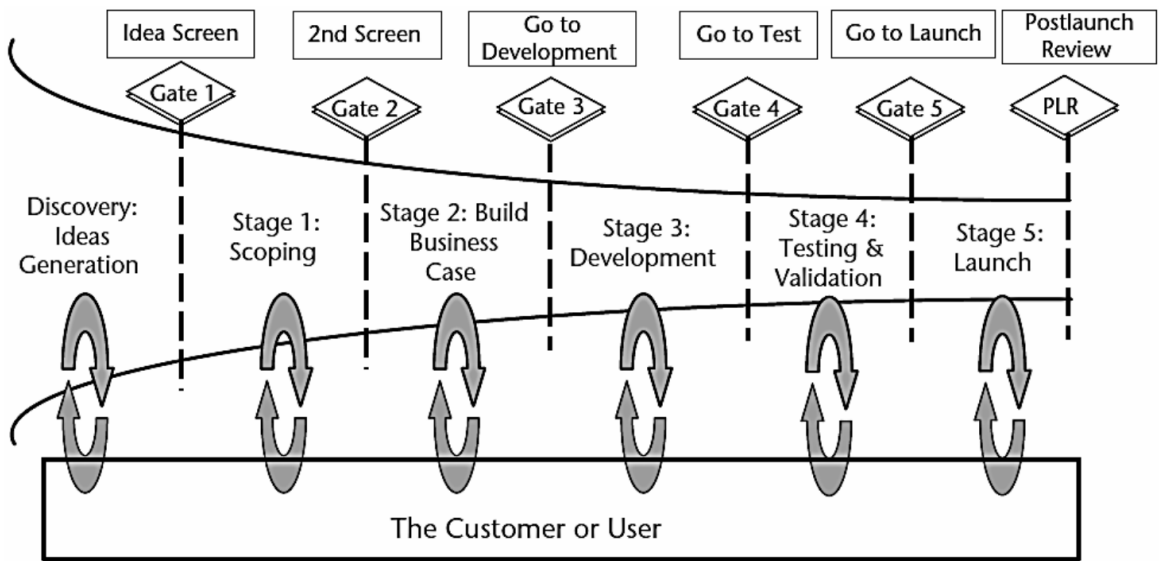

Figure 7. Stage-Gate System for new product development

Source: [Cooper, 2013, p. 29]. 


\section{Results}

\subsection{A comparison of traditional and modern models}

Reviewing the transformations and comparing the traditional and modern models of NPD is beneficial because it reveals the secrets of a really productive NPD - this, however, is not enough, since the future is too complicated, multidimensional, full of discontinuities, and fuzzy. Traditional NPD focuses on local, regional, and domestic markets or makes no distinction between them and the global market. However, NPD should take into consideration that while the quality should be the same worldwide, the new product should satisfy consumer expectations and their varied requirements at the local markets [Darasteanu, Moskalenko, 2010, p. 2]. NPD success in the international arena depends on the company's global strategy [Brentani, Kleinschmidt, Salomo, 2010, p. 143] and on solving the problem of 'innovation contradiction' [Koudal, Coleman, 2005, p. 20].

Table 3. A comparison of traditional and modern models

\begin{tabular}{|c|c|c|}
\hline & Traditional NPD model & Modern NPD model \\
\hline Metaphor & relay race & rugby \\
\hline Human capital & functional specialists & hand-picked, multidisciplinary team \\
\hline Workflow & phase to phase & start to finish \\
\hline Orientation & driven by market-pull forces & driven by technology-push forces \\
\hline Innovation & incremental, continuous & highly radical, discontinuous \\
\hline Scheme & segmented duties & interaction \\
\hline Approach & linear & integrated \\
\hline Communication & formal communications & informal communications \\
\hline Focus & local and domestic markets & global markets \\
\hline Control & planned, backward-scheduled & dynamic, goal-directed, autonomous \\
\hline User understanding & high & low \\
\hline Structure & fixed & emergent and rule-breaking \\
\hline Nature & comparatively deterministic & chaotic, unpredictable, unstable \\
\hline Array & discrete, compartmentalised & continuous, cohesive \\
\hline Values & following the rules & achievement \\
\hline Team & organisational units & cross-functional, inter-functional \\
\hline Procedure & sequential & holistic, overlapping \\
\hline
\end{tabular}

Source: Own elaboration based on: [Hines, 2016, p. 335; Darasteanu, Moskalenko, 2010; Sorli, Stokic, 2009, p. 59; Kyriazis, Massey, 2008; Hauser, Dahan, 2007; McCarthy et al., 2006; Bonner, Ruekert, Walker, 2002, p. 233; Juran et al., 1999; Paashuis, 1998, p. 28; Cordero, 1991; Bingham, Quigley, 1989; Takeuchi, Nonaka, 1986]. 
The workflow in traditional NPD models is linear, sequential, and segmented - it moves from phase to phase and its functions are specialised and subdivided. The failures of traditional methods cause costly re-works and uncertainty at top managerial level [Sänn, 2017, p. 127]. Nowadays, members of 'hand-picked, multidisciplinary teams' interact throughout the process [Takeuchi, Nonaka, 1986, p. 137].

\subsection{Counter models}

What is the opposite of NPD? Palmer uses the term 'deleting products' and mentions that recognising the decline stage of a product life cycle and making a decision about deleting or reviving a product requires tact and careful thought. He also draws a distinction between allowing 'to die gradually or suddenly killing off' [Palmer, 2009, p. 292]. New ideas are essential for enterprises that attempt to develop their 'next killer products' [Ozer, 2002, p. 2].

\subsection{Side effects}

Notwithstanding the positive aspects of NPD, it may also have some side effects and even adverse impacts, which will be discussed in this section.

Technology myopia ${ }^{1}$ is a trap that threatens NPD by shifting focus to engineering, technology, or hardware, while neglecting its non-technological aspects.

Another crucial problem, especially in high-tech firms, is the engineer-marketer conflict, which may hinder the speed, fluency, and success of NPD [Keaveney, 2008, p. 653; La Placa, 2008, p. 623]. Actually, several NPD experts who occupied positions in leading-edge and high-tech firms tend to focus on creativeness and engineering skills instead of the study of consumers [Durgee, O'Connor, Veryzer, 1998, p. 542]. Engineering design should not only ensure that the product performs the intended functions, but also be novel, meet the preferred qualifications, and have desired utilities - in other words, it 'must satisfy a set of predefined specifications' and ought to be assessed by particular standards than the metrics of marketers [Shah, Vargas-Hernandez, 2003, p. 111]. This is the root cause of the engineer-marketer conflict.

Product cannibalisation is the damaging effect that new products exert on the sales performance of existing products [Madhavi, 2014, p. 41] by eating up their demand. Its theoretical foundation can be traced to the demand theory and the concept of cross-elasticity [Kerin, Harey, Rothe, 1978, p. 25]. Extreme product cannibalism is a popular criticism of brand extension [Buday, 1989, p. 29].

The ceaseless generation of new ideas and creation of new products presents a serious challenge. As a result, a wide range of individuals, companies, markets,

1 Adapted from the term 'marketing myopia', coined by Levitt in his classic paper in the Harvard Business Review [1960]. 
and even governments suffer from innovation inefficiency and lack of well-timed technological and managerial changes.

'Innovation overload' in its common and classic sense refers to consumers' response to the ever-growing speed of innovation, knowledge, and information accrual, which seriously impairs their decision-making ability [Schiffman, Kanuk, 1997, p. 535] and interrupts the diffusion of future innovations [Herbig, Kramer, 1994, p. 46].

Customers are generally biased by their experiences, and because their desires and needs are usually encoded, mapped, configured, and represented based on their previous choices or an echo of past preferences [Goldenberg, Mazursky, 2002, p. 23], this may hinder the proliferation of new products or services.

\section{Discussion}

Critical factors on NPD are different in various studies because of differentiation in technology, structure, size, culture, strategy, stake holders, level of investment, brand credibility, managers' level of involvement, skills, background and etc. It is understood that beyond of internal factors, external issues including market pull, governmental policies, technology push, environmental aspects and social conditions effect on NPD. Therefore using innovative methods, staffing smart and creative staff, R\&D trials, monitoring the technology, brand management, analysing competitor's products, consideration of product life cycle, trend monitoring, benchmarking, continuous learning, mastery to new techniques and soft wares, inventive imitation, upbringing creative and innovative workforce, flexibility in design, notice to voice of customer, moving toward simplicity, low cost and take optimal risk and especially knowing the counter models of NPD are so important efforts to optimisation of new products.

\section{Conclusions}

New product development is a vast, multidisciplinary concept that encompasses various dimensions. Marketers, technologists, economists, academicians, politicians, and consumers perceive it from their own points of view. Although it has been part of academic deliberation only for around half a century, its application dates to the prehistoric era, and its continuous evolution testifies to its influence and importance.

NPD processes differ in length and the number of sub-processes. Their inseparable part is the generation of an idea. Almost all NPD processes start with 
idea generation and end with commercialisation, implementation, or production. These insights are rewarding, but they are not indispensable in order to follow in the same footsteps. The outcome depends on a series of indigenous and exogenous factors and unforeseen events, which is why NPD is usually a risky process.

Innovation continues to be considered as the prime engine of NPD. A significant role in shaping a company's strategy is played by consumers; bearing this in mind, it has to be emphasised that a combination and right execution of business strategy and technology strategy is necessary for long-run achievements. NPD and NSD executives should also take into consideration the side effects of their efforts, because both inhibiting and accelerating factors have impact on overall success.

\section{References}

Abernathy W.J., Clark K.B., 1985, Innovation: Mapping the winds of creative destruction, Research Policy, no. 1.

Ahonen M., 2005, Designing information systems for creative problem solving and learning, E- Business Research Forum Conference, Tampere, Finland.

Alford C.L., Mason J.B., 1975, Generating new product idea, Journal of Advertising Research, no. 6.

Anderson A.M., 2008, A framework for NPD management: Doing the right things, doing them right, and measuring the results, Trends in Food Science \& Technology, no. 19.

Atkinson R., Wial H., 2008, Boosting productivity, innovation, and growth through a national innovation foundation, Bookings, https://www.brookings.edu/research/boosting-productivity-innovation-and-growth-through-a-national-innovation-foundation/ [access: 06.10.2017].

Barczak G., Griffin A., Kahn K.B., 2009, Perspective: Trends and drivers of success in NPD practices: Results of the 2003 PDMA best practices study, Journal of product Innovation Management, no. 26 .

Bhuiyan N., 2011, A framework for successful new product development, Journal of Industrial Engineering and Management, no. 4.

Bingham F.G., Quigley C.J., Jr., 1989, Venture team application to new product development, The Journal of Business \& Industrial Marketing, no. 1.

Blythe J., 1999, Innovativeness and newness in high-tech consumer durables, Journal of Product \& Brand Management, no. 5 .

Bonner J.M., Ruekert R.W., Walker O.C., Jr., 2002, Upper management control of new product development projects and project performance, Journal of Product Innovation Management, no. 3 .

Booz Allen Hamilton Inc., 1982, New product management for 1980s, Booz Allen Hamilton Inc., New York.

Brentani U., Kleinschmidt E.J., Salomo S., 2010, Success in global new product development: Impact of strategy and the behavioral environment of the firm, Journal of Product Innovation Management, no. 27.

Buday T., 1989, Capitalizing on brand extensions, Journal of Consumer Marketing, no. 4. 
Calantone R.J., Schmidt J.B., Song X.M., 1996, Controllable factors of new product success: A cross-national comparison, Marketing Science, no. 4.

Clark K.B., Fujimoto T., 1991, Product development performance: Strategy, organization, and management in the world auto industry, Harvard Business School Press, Boston.

Cooper R.G., 1983, A process model for industrial new product development, IEEE Transactions on Engineering Management, no. (1).

Cooper R.G., 2013, New products: What separates the winners from the losers and what drives success, [in:] PDMA handbook of new product development, ed. K.B. Kahn, John Wiley \& Sons, Inc., Hoboken.

Cooper R.G., 2015, The latest view: The Stage-Gate® system for new product development, Product Development Institute Inc., http://www.bobcooper.ca/images/files/articles/2/2-2The-Latest-View-on-Stage-Gate.pdf [access: 06.10.2017].

Cordero R., 1991, Managing for speed to avoid product obsolescence: A survey of techniques, Journal of Product Innovation Management, no. 4.

Crawford C.M., 1972, Strategies for new product development: Guidelines for a critical company problem, Business Horizons, no. 6.

Darasteanu C., Moskalenko M., 2010, New product development process goes global: A qualitative study of rethinking traditional concepts, master's thesis, Umeå School of Business, Sweden.

Davari Nikou K., 2011, Factory-less manufacturing: The new paradigm of entrepreneurship in $3^{\text {rd }}$ millennium, Farsar, Urmia, Iran

Deppe L. et al., 2002, The holistic view of the front end of innovation, Conference on IMTs and New Product Development, Mantova, Italy.

Durgee J.F., O'Connor G.C., Veryzer R.W., Jr., 1998, Using mini-concepts to identify opportunities for really new product functions, Journal of Consumer Marketing, no. 6.

Ernst H., 2002, Success factors of new product development: A review of the empirical literature, International Journal of Management Reviews, no. 1.

Felekoglu B., Maier A.M., Moultrie J., 2013, Interactions in new product development: How the nature of the NPD process influences interaction between teams and management, Journal of Engineering and Technology Management, no. 30.

Filippini R., Salmaso L., Tessarolo P., 2004, Product development time performance: Investigating the effect of interactions between drivers, Journal of Product Innovation Management, no. 21.

Flint D.J., 2002, Compressing new product success-to-success cycle time deep customer value understanding and idea generation, Industrial Marketing Management, no. 31.

Goldenberg J., Lehmann D.R., Mazursky D., 2001, The idea itself and the circumstances of its emergence as predictors of new product success, Management Science, no. 47.

Goldenberg J., Mazursky D., 2002, Creativity in product innovation, Cambridge University Press, Cambridge.

Gremyr I., Witell L., Löfberg N., Edvardsson B., Fundin A., 2014, Understanding new service development and service innovation through innovation modes, Journal of Business \& Industrial Marketing, no. 2.

Griffin A., 1993, Metrics for measuring product development cycle time, Journal of Product Innovation Management, no. 10.

Griffin A., 1992, Evaluating QFD's use in US firms as a pocess for developing products, Journal of Product Innovation Management, no. 3.

Harmancioglu N., McNally R.C., Calantone R.J., Durmusoglu S.S., 2007, Your new product development (NPD) is only as good as your process: an exploratory analysis of new NPD process design and implementation, R\&D Management, no. 5. 
Hauser J.R., Dahan E., 2007, New product development, [in:] Marketing management: Essential marketing knowledge and practice, R. Grover, N.K. Malhotra (eds.), McGraw Hill, Inc., Columbus Ohio.

Haverila M.J., 1995, The role of marketing when launching new products into the international markets: An empirical study in Finnish high-technology companies, Tampere University of Technology, Finland.

Herbig P.A., Kramer H., 1994, The effect of information overload on the innovation choice process, Journal of Consumer Marketing, no. 2.

Herstatt et al., 2004, Reducing project related uncertainty in the 'fuzzy front end' of innovation: A comparison of German and Japanese product innovation projects, International Journal of Product Development, no. 1.

Higham W., 2009, The next big thing: Spotting and forecasting consumer trends for profit, Kogan Page, London - Philadelphia.

Hines A., 2016, Future friendly design: Designing for and with future consumers, [in:] M.G. Luchs et al., Design thinking: New product development essentials for the PDMA, John Wiley \& Sons, Hoboken - New Jersey.

Hopkins D.S., Bailey E.L., 1971, New product pressures, Conference Board Record, June.

Iamratanakul S., Patanakul P., Milosevic D., 2008, Innovation and factors affecting the success of NPD projects: Literature explorations and descriptions, International Journal of Management Science and Engineering Management, no. 3.

Jaruzelski B., Holman R., Duad O., 2001, Next-generation product development, Strategy+Business, https://www.strategy-business.com/article/00076?gko=90b0b [access: 06.10.2017].

Johannessen J., Olsen B., Lumpkin G.T., 2001, Innovation as newness: What is new, how new, and new to whom?, European Journal of Innovation Management, no. 4.

Jugend D., Silva S.L. da, 2012, Integration in new product development: Case study in a large Brazilian high-technology company, Journal of Technology Management \& Innovation, no. 1.

Juran J.M. et al., 1999, Juran's quality handbook, McGraw-Hill, New York.

Kahn K.B., Barczak G., Nicholas J., Ledwith A., Perks P.J., 2012, An examination of new product development best practice, Journal of Product Innovation Management, no. 29.

Keaveney S.M., 2008, The blame game: An attribution theory approach to marketer-engineer conflict in high-technology companies, Industrial Marketing Management, no. 37.

Kerin R.A., Harey M.G., Rothe J.T., 1978, Cannibalization and new product development, Business Horizons, no. 5.

Khurana A., Rosenthal S.R., 1998, Towards holistic 'front ends' in new product development, Journal of Product Innovation Management, no. 1.

Kotler P., Armstrong G., 2010, Principles of marketing, Pearson Education Inc., Upper Saddle River.

Koudal P., Coleman G. C., 2005, Coordinating operations to enhance innovation in the global corporation, Strategy and Leadership, no. 4.

Krishna A., Kautish P., 2012, Innovation in new service development: The role of customer, International Conference on Trade, Tourism and Management, December 21-22, 2012, Bangkok, Thailand.

Krishnan V., Ulrich K.T., 2001, Product development decisions: A review of the literature, Management Science, no. 1.

Kowalkowski C., Kindström D., Alejandro T., Brege S., Biggemann S., 2012, Service infusion as agile incrementalism in action, Journal of Business Research, no. 6. 
Kowalkowski C., Witell L., Gustafsson A., 2013, Any way goes: Identifying value constellations for service infusion in SMEs, Industrial Marketing Management, no. 42.

Kyriazis E., Massey G., 2008, The effects of formal and informal communication between marketing and RED managers during new product development projects, Proceedings of the Academy of Marketing Conference, Marketing Academy, Aberdeen.

La Placa P.J., 2008, Marketing of high-tech products, services and innovations, Industrial Marketing Management, no. 37.

Levitt T., 1966, Innovative imitation, Harvard Business Review, September-October.

Little A.D., 2005, Innovation excellence 2005: How companies use innovation to improve profitability and growth, http://www.adlittle.com/downloads/tx_adlreports/ADL_Global_Innovation_Excellence_Survey_2005.pdf [access: 06.10.2017].

Lovelock C.H., Wirtz J., 2014, Services marketing: People, technology, strategy, Prentice Hall, Boston.

Lovelock C.H., Wirtz J., Chew P., 2012, Essentials of services marketing, Pearson Education, Singapore.

Madhavi K., 2014, The impact of product cannibalization on consumer purchasing decision: An attitudinal conflict paradigm, International Journal of Research in Business Management, no. 8.

McCarthy I.P., Tsinopoulos C., Allen P., Rose-Anderssen C., 2006, New product development as a complex adaptive system of decisions, The Journal of Product Innovation Management, no. 23 .

Mendes G.H.S., Ganga G.M.D., 2013, Predicting success in product development: The application of principal component analysis to categorical data and binomial logistic regression, Journal of Technology Management \& Innovation, no. 3.

Micheal K., Rochford L., Wotruba T.R., 2003, How new product introductions affect sales management strategy: The impact of type of 'newness' of the new product, Journal of Product Innovation Management, no. 20.

Mishra A., Chandrasekaran A., MacCormack A., 2015, Collaboration in multi-Partner R\&D projects: The impact of partnering scale and scope, Journal of Operations Management, no. 33-34.

Moreau E.B., Tether B.S., 2010, From transacting to inter-relating? Service innovation amongst UK manufacturers, Conference on Opening up Innovation: Strategy, Organization and Technology, Imperial College, London.

Morgan T. et al., 2015, The dark side of the entrepreneurial orientation and market orientation interplay: A new product development perspective, International Small Business Journal, no. 7.

Muller N.D., 2015, Design thinking versus lean startup: Do these methods lead to more creative and customer focused ideas?, Master's thesis, Erasmus University, Rotterdam.

Murthy D.N.P., Rausand M., Osteras T., 2008, Product reliability: Specification and performance, Springer, London.

Ng I.C.L., 2014, Creating new markets in the digital economy, Cambridge University Press, New York.

Nordlund H., Poskela J., 2005, Front end customer orientation: The effect of innovation radicalness, Proceedings of the XVI ISPIM Conference, June19-22, 2005, Porto, Portugal.

Owens J.D., Davies J., 2000, The importance of a new product development process: Getting started, $1^{\text {st }}$ European Conference on KM, Bled School of Management, Bled, Slovenia. 
Ozer M., 2002, What do we know about new product idea selection?, Center for Innovation Management Studies at North Carolina State University.

Ozer M., Chen Z., 2006, Do the best new product development practices of US companies matter in Hong Kong?, Industrial Marketing Management, no. 35.

Paashuis V., 1998, The organisation of integrated product development, Springer, London.

Palmer A., 2009, Introduction to marketing: Theory and practice, Oxford University Press, New York.

Pekkarinen O., Salminen R.T., 2013, Developing industrial solution offerings: A framework and management guidelines, Journal of Business Marketing Management, no. 3.

Prahalad C.K., Hamel G., 1990, The core competences of the corporation, Harvard Business Review, no. 3.

Poolton J., Barclay I., 1998, From past research to future applications, Industrial Marketing Management, no. 27.

Rhee B.V.D., 2015, Innovate or perish: New product development as a key domain of operations management, https://www.nyenrode.nl/docs/default-source/pdf $\% 27 \mathrm{~s} / \mathrm{pdf} \% 27 \mathrm{~s}$ - faculteit- research/oraties-emeritaatsredes/bo-van-de-rhee_inaugural_lecture.pdf?sfvrsn $=719$ bc414_2 [access: 06.10.2017].

Sänn A., 2017, The preference-driven lead user method for new product development: A comprehensive way to stimulate innovations with internal and external sources, Springer, Wiesbaden.

Santamaría L., Nieto M.J., Miles I., 2012, Service innovation in manufacturing firms: Evidence from Spain, Technovation, no. 2.

Schiffman L.G., Kanuk L.L., 1997, Consumer behavior, Prentice Hall, Upper Saddle River.

Scott E., Govender T., Merwe N. van der, 2016, The X-factor of cultivating successful entrepreneurial technology-enabled start-ups: Informing science, International Journal of an Emerging Trans Discipline, no. 19.

Shah J.J., Kulkarni S.V., Vargas-Hernandez N., 2000, Evaluation of idea generation methods for conceptual design: Effectiveness metrics and design of experiments, Journal of Mechanical Design, no. 122.

Shah J.J., Vargas-Hernandez N., 2003, Metrics for measuring ideation effectiveness, Design Studies, no. 24.

Shekar A., 2007, An innovative model of service development: A process guide for service managers, The Public Sector Innovation Journal, no. 1.

Song X.M., Neeley S.M., Zhao Y., 1996, Managing RED marketing integration in the new product development process, Industrial Marketing Management, no. 25.

Sorli M., Stokic D., 2009, Innovating in product/process development: Gaining dace in new product development, Springer, London.

Suomala P., Jokioinen L., 2003, The patterns of success in product development: a case study, European Journal of Innovation Management, no. 4.

Swink M., Song M., 2007, Effects of marketing-manufacturing integration on new product development time and competitive advantage, Journal of Operations Management, no. 25.

Takeuchi H., Nonaka I., 1986, The new product development game, Harvard Business Review, January-February.

Tatikonda M.V., Zeithaml V.A., 2002, Managing the new service development process: Multi-disciplinary literature synthesis and directions for future research, [in:] T. Boone, R. Ganeshan, New directions in supply-chain management: Technology, strategy, and implementation, AMACOM, New York. 
Ulaga W., Reinartz W. J., 2011, Hybrid offerings: How manufacturing firms combine goods and services successfully, Journal of Marketing, no. 6.

Ulrich K., Eppinger S., 1995, Product design and development, McGraw-Hill Inc., New York.

Verganti R., 1997, Leveraging on systematic learning to manage the early phases of product innovation projects, R\&D Management, no. 4.

Wheelwright S.C., Clark K.B., 2007, Leading product development: The senior manager's guide to creating and shaping the enterprise, Free Press, New York.

Wilson A., Zeithaml V.A., Bitner M.J., Gremler D.D., 2012, Services marketing: Integrating customer focus across the firm, McGraw-Hill Inc., New York.

Witell L., Edvardsson B., Meiren T., Schäfer A., 2014, New service development in manufacturing firms: Similarities and differences with new service development and new product development, Journal of Applied Management and Entrepreneurship, no. 3.

Zapata A.R.P, Cantú S.O., 2008, Gestion estrategica de la tecnologia en el predesarrollo de nuevos productos, Journal of Technology Management \& Innovation, no. 3.

Kamran Davari Nikou (®) k.d.nikoo@gmail.com

Dokuz Eylul University, Graduate School of Social Sciences, Department of Business

Administration, 35390 Buca, Izmir, Turkey 